This item was submitted to Loughborough's Research Repository by the author.

Items in Figshare are protected by copyright, with all rights reserved, unless otherwise indicated.

\title{
LGBTIQ psychology in context
}

PLEASE CITE THE PUBLISHED VERSION

https://doi.org/10.1017/9781108303750

PUBLISHER

Cambridge University Press

VERSION

AM (Accepted Manuscript)

PUBLISHER STATEMENT

This material has been published in Lesbian, Gay, Bisexual, Trans, Intersex and Queer Psychology: An introduction, 2nd ed, edited by Sonja J. Ellis, Damien W. Riggs and Elizabeth Peel https://doi.org/10.1017/9781108303750. This version is free to view and download for private research and study only. Not for re-distribution or re-use. (c) Cambridge University Press.

\section{LICENCE}

All Rights Reserved

\section{REPOSITORY RECORD}

Ellis, Sonja J., Damien Riggs, and Elizabeth Peel. 2019. "LGBTIQ Psychology in Context". figshare. https://hdl.handle.net/2134/36932. 
From Ellis, S.J., Riggs, D.W. \& Peel, E. (2020). Lesbian, Gay, Bisexual, Trans, Intersex \& Queer Psychology: An introduction. $2^{\text {nd }}$ Ed. Cambridge University Press.

\section{Chapter 1: LGBTIQ Psychology in Context}

\section{Chapter Overview}

In this opening chapter we situate the field of LGBTIQ psychology in relationship to broader global and political contexts, as well as introducing the scope of the book and attending to specific issues that continue to shape the field. Specifically, we:

- Define LGBTIQ psychology and LGBTIQ psychologists;

- Highlight challenges and positive changes for LGBTIQ people in different parts of the world;

- Explore how different political ideologies shape understanding of LGBTIQ people's lives;

- Discuss terminology, and how to navigate different language and terms used in this book.

\section{Introduction: Contextualising LGBTIQ Psychology}

It is a decade since the publication of our first textbook in the field of sexualities and gender, namely Lesbian, Gay, Bisexual, Trans and Queer Psychology (Clarke, Ellis, Peel \& Riggs, 2010). Much has happened in the field and globally in the intervening ten years. Research focused specifically on the lives of bisexual, intersex, transgender and gender diverse people has grown over that time. Also, there has been much positive social change for LGBTIQ people in some parts of the world, though in other parts of the world there has been erosion or stasis in the human rights of LGBTIQ people.

If you are a psychology student you will find it easy to make connections between the areas covered in Lesbian, Gay, Bisexual, Trans, Intersex and Queer Psychology and parts of your course curriculum typically labelled 'social psychology', 'developmental psychology' and 'health psychology'. What you will find different, however, is that the field we delineate and the research we describe challenges the heteronormativity and cisgenderism prevalent in the discipline of psychology and other social sciences. In essence, LGBTIQ psychology, sometimes known as the psychology of sexualities, is a field of psychology that aims to challenge the primary and often normative focus on heterosexual cisgender people within society more broadly and academic research specifically. LGBTIQ psychology also provides a range of affirmative psychological, psychosocial and sociological perspectives on the lives and experiences of lesbian, gay, bisexual, transgender, intersex and queer people. It is important to note that our approach to mapping out the field is an inclusive 
From Ellis, S.J., Riggs, D.W. \& Peel, E. (2020). Lesbian, Gay, Bisexual, Trans, Intersex \& Queer Psychology: An introduction. $2^{\text {nd }}$ Ed. Cambridge University Press. one. We liberally draw on research conducted across the social sciences to scope out the shape of the field in a deliberately more expansive way than that typical of positivist-empiricist psychology.

The goal of overcoming discrimination and making the world a better place for groups and individuals who are marginalised is one shared by many social scientists who conduct research on LGBTIQ people's lives But, of course, this is an aspiration of many budding psychologists and social scientists with a general interest in social justice. As such, we would encourage you when reading this book to make connections between LGBTIQ-specific concerns and others axes of marginalisation and privilege - across (dis)ability; 'race', ethnicity and culture; religion; social class and income inequality. In many cases in this book an intersectional approach will be made explicit, although as a reader interested in positive social change and non-heterosexist and non-cisgenderist approaches to research and practice we are sure that you will extrapolate further. You may also make connections with your own life and experiences. We would encourage this, and encourage you also to reflect on your own perceptions when considering the 'discussion questions' and 'classroom exercises', which appear at the end of each chapter.

Who is an LGBTIQ psychologist? Any psychologist or social scientist who has an academic interest in sex, gender and sexuality diversity can label themselves as an LGBTIQ psychologist, and indeed some researchers who explicitly identify themselves as heterosexual work in this field (see Peel \& Coyle, 2004). You too can be an LGBTIQ psychologist. Famously, when four UK psychologists - Celia Kitzinger, Sue Wilkinson, Adrian Coyle and Martin Milton were working to establish what was known then as 'Lesbian and Gay Psychology' within the British Psychological Society (BPS) in the 1990s they discussed this very issue in The Psychologist. They wrote that 'no implications are intended as to the characteristics of the psychologists themselves: a "lesbian and gay psychologist" can be heterosexual, just as a "social psychologist" can be antisocial or a "sports psychologist" a couch potato' (Kitzinger, Wilkinson, Coyle \& Milton, 1998, p. 532). In this book we use the LGBTIQ acronym to describe the field because it enables specific sexualities, genders, and sex variations to be made visible, though as we will discuss throughout this book there are other populations not covered by the acronym, so it is important to be mindful of other groups not explicitly named (Clarke \& Peel, 2007; Peel \& Riggs, 2016).

In what remains of this opening chapter we will situate LGBTIQ psychology within contemporary international and social-political contexts. In so doing you will see that the situation for the development of LGBTIQ knowledge and for LGBTIQ individuals and communities is bifurcated. By that we mean that in some parts of the (largely Western) world LGBTIQ people enjoy more human rights and protections than ever before, whilst in other jurisdictions extreme 
From Ellis, S.J., Riggs, D.W. \& Peel, E. (2020). Lesbian, Gay, Bisexual, Trans, Intersex \& Queer Psychology: An introduction. $2^{\text {nd }}$ Ed. Cambridge University Press.

forms of discrimination endure. It is important to note that though we - Sonja, Damien and Elizabeth - have lived through challenging social and legal frameworks in the past, we reside in New Zealand, Australia and the UK respectively and as such are comparatively privileged. As Box 1.1 below highlights, not being heterosexual and cisgender is still punishable by death in some African and Asian countries. This is very sobering for those of us whose lives are protected under equalities legislation. We are also privileged by dint of our social class, ethnicity and employment in universities. It is very important to recognise how different identities and forms of recognition and resource intersect with sex, sexuality and gendered identities. For many LGBTIQ people there are aspects of our identities that garner discrimination (e.g.,

heterosexism, cisgenderism, sexism, racism) in tandem with that which is socially advantageous (e.g., social capital, white privilege). It is also important to reflect on 'Western' and 'Eastern' or 'Global North' and 'Global South' perspectives on LGBTIQ people and issues. Commonly, 'western' approaches and thought on diversity with regard to sex, sexualities and genders are viewed as 'progressive' - and in many instances they may well be. However, is it equally important to consider alternate understandings from 'non-western' countries and perspectives. To take just one example, in Thailand and the Philippines in the late 1960s and early 1970s lesbian, gay and transgender social scenes were developing (Jackson, 2001; 2016). This is around the same historical moment of the famous Stonewall Riots (New York in 1969), widely seen as the watershed in the development of lesbian and gay visibility and rights. Yet social revolutions led by lesbian, gay and transgender people in Thailand and the Philippines are rarely spoken about in the same breath as those that took place as part of the Stonewall Riots. Food for thought as we now briefly consider some aspects of the international context.

\section{Challenges and Positive Changes in a Globalised World}

Each year the International Lesbian, Gay, Bisexual, Trans and Intersex Association (ILGA) publishes a world survey on laws related to sex, gender and sexuality. While in general terms legal protections for LGBTIQ people have increased over time in many parts of the world, as Mapp and Gabel (2017) note 'human rights can never be taken for granted in any nation' (p. 2). In May 2017, for instance, there were 124 States - mostly United Nations member States plus Taiwan and Kosovo - where there were no legal penalities for consenting, private, same-gender sexual activity (Carroll \& Mendos, 2017). However, as Box 1.1 shows, in 2018 there were 70 criminalising States, of which 45 (24 in Africa, 13 in Asia, six in the Americas and two in Oceania) apply the law to women as well as men. The latest ILGA report highlights that in the southern parts of the Middle East, particularly Saudi Arabia and Yemen, the death penalty is very much a current issue. In countries such as Libya, Egypt, Turkey, Morocco, and Tunisia, as well as historically Islamic states, expressions of sexual and gender 
From Ellis, S.J., Riggs, D.W. \& Peel, E. (2020). Lesbian, Gay, Bisexual, Trans, Intersex \& Queer Psychology: An introduction. ${ }^{\text {nd }}$ Ed. Cambridge University Press.

diversity can be very dangerous.

Box 1.1: Highlight: Criminalization of LGBTIQ people across the globe

Criminalization occurs in 70 countries:

Africa (Algeria, Angola, Botswana, Burundi, Cameroon, Central African Republic, Comoros, Egypt, Eritrea, Ethiopia, Gambia, Ghana, Guinea, Kenya, Liberia, Libya, Malawi, Mauritania, Mauritius, Morocco, Namibia, Nigeria, Senegal, Sierra Leone, Somalia, South Sudan, Sudan, Swaziland, Tanzania, Togo, Tunisia, Uganda, Zambia and Zimbabwe)

Asia (Afghanistan, Bangladesh, Bhutan, Brunei, Iran, Kuwait, Lebanon, Malaysia, Maldives, Myanmar, Oman, Pakistan, Qatar, Saudi Arabia, Singapore, Sri Lanka, Syria, Turkmenistan, United Arab Emirates, Uzbekistan and Yemen)

Caribbean (Antigua and Barbuda, Barbados, Dominica, Grenada, Guyana, Jamaica, St. Kitts and Nevis, St. Lucia and St. Vincent and the Grenadines)

South Pacific (Kiribati, Papua New Guinea, Samoa, Solomon Islands, Tonga and Tuvalu)

Entities (Cook Islands, Gaza, South Sumatra and Aceh Provinces of Indonesia)

Punishable with the Death Penalty in 10 countries:

Africa (Mauritania, Sudan, as well as parts of Nigeria and Somalia)

Asia (Brunei, Iran, Qatar, Saudi Arabia, United Arab Emirates and Yemen)

So-called anti-propaganda laws inhibit LGBT advocacy in 3 countries:

Africa (Nigeria)

Europe (Lithuania, Russia)

Source: Human Rights Campaign. Updated September 2018

http://assets.hrc.org//files/assets/resources/Criminalization-Map-

042315.pdf? ga=2.91044569.2112028709.1499089395-

$\underline{1169923101.1499089395}$

If we take marriage equality between same and different-gender couples as a litmus test of the human rights status of LGBTIQ people globally we can see, in Box 1.2, that in much of the world equal access to marriage is not a reality for those in same-gender relationships. As Kitzinger and Wilkinson (2006) argued, equal access to marriage irrespective of gender is important because it 'would mean that categories like "male" and "female", and "lesbian" / "gay" / "bisexual" etcetera do not have to be continually reproduced. What's needed is not "same- 
From Ellis, S.J., Riggs, D.W. \& Peel, E. (2020). Lesbian, Gay, Bisexual, Trans, Intersex \& Queer Psychology: An introduction. $2^{\text {nd }}$ Ed. Cambridge University Press.

sex marriage" or "gay marriage", just equal access to marriage (and to civil partnership) for everyone regardless of gender and sexuality' (p. 177). It has been suggested that 'the (hetero)normativity of marriage rites are fractured and reconfigured by the ongoing business of queer folks getting hitched' (Peel, 2015, p.113), although there is an ongoing debate about whether LGBTIQ people are assimilated into heteronormative social structures or act in a transformative way on social norms, an issue we will return to in Chapter 6.

\section{Box 1.2: Highlight: Marriage equality around the world}

\section{Same-gender marriage is legal in 26 countries:}

Argentina, Australia, Austria, Belgium, Brazil, Canada, Colombia, Denmark, Finland, France, Germany, Iceland, Ireland, Luxembourg, Malta, Mexico, the Netherlands, New Zealand, Norway, Portugal, Spain, South Africa, Sweden, the United Kingdom, the United States of America and Uruguay.

Source: Human Rights Campaign. Updated January 2019 http://assets.hrc.org//files/assets/resources/WorldMarriageMap.pdf? ga=2.95 837023.2112028709.1499089395-1169923101.1499089395

As we mentioned above, the world is bifurcated in terms of LGBTIQ people's human rights: they are far from universal. Imagine, for example, the life of a lesbian couple in Demark where legal recognition of same-gender relationships has existed since 1989 in comparison to a Nigerian couple, where since 2014 under the Same-sex Marriage (Prohibition) Act, 2013 a person who 'directly or indirectly makes public show of same-sex amorous relationship[s]' may receive a sentence of up to ten years imprisonment (Carroll \& Mendos, 2017). If we take the legal situation in the countries of two of us - Damien and Sonja - as another example, legal frameworks differ between Australia and New Zealand, two geographically proximate countries. New Zealand has allowed same-gender couples to marry since August 2013 and many Australian same-gender couples travelled there to access marriage until it finally became legal in Australia in December 2017. In Damien's state of South Australia legislation allowing samegender couples to openly adopt came into effect in February 2017, whereas this has been legal in New Zealand from 2013, and in The Netherlands since 2001.

\section{Neoliberalism and Right-Wing Extremism}

Since the 1980s neoliberalism has become a dominant socio-political framework in the Western world, having been first implemented in Chile in the 1970s. It can be defined as 'a constellation of economic and social policies and ideologies designed to introduce or increase capitalist, market-based competition in areas of social life previously considered beyond the reach of the economic' (Grzanka, Mann, \& Elliott, 2016, p. 297). Neoliberalism is a concept that is characterised by privatization, deregulation, free markets and free trade, 
From Ellis, S.J., Riggs, D.W. \& Peel, E. (2020). Lesbian, Gay, Bisexual, Trans, Intersex \& Queer Psychology: An introduction. $2^{\text {nd }}$ Ed. Cambridge University Press.

and a withdrawal of the State from many aspects of social life (Gill \& Scharff, 2011). In psychological terms neoliberalism and individualism are closely linked, and the neoliberal subject is one which is self-managing, self-disciplining, enterprising and autonomous. Neoliberalism is characterised by consumerism and consumption. In terms of diverse sexualities and genders - and LGBTIQ groups and activism - neoliberalism plays out in complicated ways. We see, for instance, the corporatisation of diversity. In other words, prior to the 1980s, in many parts of the world LGBTIQ groups were excluded from the State, but a combination of factors including neoliberal modernity has seen an incorporation of LGBTIQ groups in ways which have deradicalised those groups. In some cases, this co-option by the State has meant increased visibility without better rights (McGee \& Kampwirth, 2015).

Another way that corporatisation happens is through marketization. Gay men especially are 'represented as consuming citizens; the "pink pound" ripe for business to harvest' (Peel \& Harding, 2006, p. 661) and more broadly LGBTIQ people are seen as markets to be targeted. A clear example of this can be seen in how public Pride parades - which happen in many parts of the world including Hong Kong, Japan, South Korea, Thailand and Vietnam as well as across Europe, Australasia, and the Americas - have, in many places, moved from demonstration, protest and celebration to commercialization. This commercialization occurs in myriad forms including Pride sponsorship by alcohol companies (Adams, McCreanor \& Braun, 2007) via largely for profit private companies (Olson, 2017). On the one hand neoliberalism shapes LGBTIQ communities as niche markets, whilst on the other, narratives of affluence should, as Matthews and Besemer (2015) suggest based on research on LGBT deprivation in Scotland, be viewed with caution.

[Image 1.1 London Pride parade on the 7 July 2018 in central London, UK. Thirty thousand marched through central London for the city's annual LGBT Pride celebration. (Photo by Sam Mellish / In Pictures via Getty Images)

Image 1.2 Pride Parade in Halifax, Nova Scotia, Canada

2012 https://www.gettyimages.co.uk/detail/photo/pride-parade-royalty-freeimage/157735844 ]

Alongside the multiple impacts of neoliberalism on sex, gender and sexual diversity, and indeed the organisation and practice of psychology itself (Das, 2016; Grzanka \& Miles, 2016), the socio-political context is also challenged by the rise of right-wing extremism and populism. In the last decade there have been political events across the world that have resulted in a backlash against LGBTIQ people and a retrenchment from progressive legal frameworks. In Russia, for example, the 2013 Article 6.21 (Promotion of Non-Traditional Sexual Relations Among Minors) in Federal Law was used in 2015 to prosecute a St 
From Ellis, S.J., Riggs, D.W. \& Peel, E. (2020). Lesbian, Gay, Bisexual, Trans, Intersex \& Queer Psychology: An introduction. $2^{\text {nd }}$ Ed. Cambridge University Press.

Petersburg LGBT youth work organisation. There has also been pushback against the increasing visibility of LGBTIQ issues and organisations in Africa and Asia. Since 2016 in Tanzania there has been an ongoing persecution of LGBTIQ people, and police in Egypt have used online dating applications (including the dating app Grindr) to arrest and detain LGBTIQ people. In Indonesia 'The Circular to All Broadcasting Companies on Effeminate Men' prohibits all broadcasting companies from representing sexual and gender diversity in men (Carroll \& Mendos, 2017). Also in 2016 two massacres in gay bars were recorded. In Mexico, six people were murdered at a bar in the city of Xalapa (Murphy, 2017). In the city of Orlando, in the United States, 49 people were murdered, most of whom were Latinx (Ramirez, Gonzalez \& Galupo, 2017). In 2017 in Chechnya the United Nations reported the opening of a detention centre by Chechnyan officials where (perceived) gay and bisexual men detainees were subject to physical and verbal abuse, tortured with electric shocks and killed (Mapp \& Gabel, 2017).

The news of the UK's decision to leave the European Union in 2016 was followed by reports of a rise in Britain of hate crimes, including homophobic and transphobic violence (Townsend, 2016). As well as anti-LGBTIQ hate crime the spread of populist political discourse in Europe and elsewhere raises serious issues for LGBTIQ communities because, as ILGA note; 'politicians either use the community as a scapegoat or directly appeal for their votes in an attempt to prove their "human rights credentials"' (Carroll \& Mendos, 2017, p. 11). The pace that can occur in fluctuation between progressive and regressive social change is neatly illustrated by the rights of transgender people in the United States. In 2016 Obama's administration removed the ban on transgender people serving in the US military, and in 2017 Trump's administration reinstated the ban (Wilts, 2017); something condemned by psychologists in Britain as well as elsewhere (BPS, 2017).

\section{A Note on Terminology}

The terminology used in the field of LGBTIQ psychology can feel like shifting sands, indeed the acronym LGBTIQ does not easily trip off the tongue. As we said at the start of this chapter we use the acronym LGBTIQ to label the field because specific sex variations, sexualities and genders are made visible. You will see variation in how this acronym is constituted in different studies, in the USA especially GLBT is common, but we prefer to list lesbian ahead of gay for feminist reasons. A comparatively recent encyclopedia in the area used the LGBTQ acronym (Goldberg, 2016), but we feel that given people born with intersex variations are often either especially marginalised or rendered invisible in the field, the explicit inclusion of 'I' is important. Some authors choose to vary the ordering of the acronym (e.g., TBQILB) - or avoid an acronym altogether preferring 'gender and sexuality' or 'sexualities and gender' - and each of these 
From Ellis, S.J., Riggs, D.W. \& Peel, E. (2020). Lesbian, Gay, Bisexual, Trans, Intersex \& Queer Psychology: An introduction. $2^{\text {nd }}$ Ed. Cambridge University Press.

approaches has their utility and place. Although not used in this book, you will also see other variations on this acronym - such as LGBTIQA+ and LGBTIQAA used in other contexts to explicitly include agender, asexual, and/or ally persons.

[Image 1.3 Kinnar Maa Trust gives psychosocial support to Hijra. Organisers from the Trust's skill development unit wait to participate in a fundraising event for the transgender community in Mumbai, India, 20 September

2018. (Photo by Kunal Patil/Hindustan Times via Getty Images)]

In this introductory context, a consistent and explicit approach to naming is in our view the most helpful. In general, you will find the most up-to-date and least pathologising terminology used throughout. For example, we do not use the clinically commonplace language of 'disorder of sex development', rather we use the phrase people born with intersex variations - putting people first. We avoid the terms 'homosexual' and 'homosexuality' (unless historically appropriate) because of their pathologising connotations, and rather than 'same-sex' and 'opposite-sex' we use 'same-gender' and 'different-' or 'mixed-gender' for a number of reasons: first, to displace 'sex', with its often biological associations; and second, not to position different genders as diametrically opposed as we see this as an unhelpful way to conceptualise the dynamic between people.

We have thought carefully about the language and concepts we use, and while a glossary of key terms is provided, we would encourage you as the reader to reflect on the terms and language you use to describe people of diverse sexes, genders and sexualities. There can often be worry about getting language 'right' and aiming to circumvent any possible faux pas, or communicative discomfort, when interacting across diversity - this can sometimes work successfully and can sometimes have unintended consequences and undesirable effects. Considering the terms used in LGBTIQ Psychology should not only help in increasing insight into 'appropriate' rather than problematic terminology but doing so too, as a psychologist, helps to address the 'differences-as-deficits' model (Herek, 2010) historically embedded in the discipline (Hammack et al., 2013) and make a contribution to overcoming heterosexism and cisgenderism in psychology (Ansara \& Hegarty, 2012).

\section{Concluding Thoughts}

We have argued in this introductory chapter that the socio-political context for LGBTIQ people is a complex one marked by both progressive social change (sometimes under a neoliberal or populist banner) and backlash and retrenchment of rights and protections. This means that there is much for LGBTIQ psychologists and social scientists to do. We hope that you will use this book as an opportunity to not only gain insight into the contours of the field, but also as a source of inspiration for your own research into sex, gender and sexual diversity. 
From Ellis, S.J., Riggs, D.W. \& Peel, E. (2020). Lesbian, Gay, Bisexual, Trans, Intersex \& Queer Psychology: An introduction. ${ }^{\text {nd }}$ Ed. Cambridge University Press.

\section{Discussion Questions}

1) What are the pros and cons of neoliberalism with regard to diverse sexes, sexualities and genders?

2) Having read Ansara and Hegarty (2012), what other forms of cisgenderism can you identify either in psychological research, or in society?

\section{Classroom Exercises}

1) Taking your own country as the reference point spend some time researching what, in the last ten years, has happened with respect to LGBTIQ issues. You may wish to separate sex, sexualities and genders in your search. Find examples of legislative changes, social changes and attitudinal changes. Discuss your findings, and/or compare your findings to similar searches conducted on a different jurisdiction or part of the world.

2) Draw your own biographical timeline from when you were born to your current age. On this timeline mark down any messages you have received about LGBTIQ people and issues, noting the context in which these occurred (e.g., school, peers, family, the media). Use your own timeline as a basis for discussion with a partner - compare and contrast key points and messages on your respective timelines. If you were to project into the future discuss the when, what and where of information about LGBTIQ people and issues in 10, $20,30,40$ or 50 years time.

\section{Further Reading}

Ansara, Y. G. \& Hegarty, P. (2012). Cisgenderism in psychology: Pathologising and misgendering children from 1999 to 2008. Psychology \& Sexuality, 3(2), 137160.

Hammack, P. L., Mayers, L. \& Windell, E. P. (2013). Narrative, psychology and the politics of sexual identity in the United States: from 'sickness' to 'species' to 'subject'. Psychology \& Sexuality, 4(3), 219-243.

Jackson, P. (2016). First queer voices from Thailand: Uncle Go's advice columns for Gays, Lesbians and Kathoeys. Hong Kong: Hong Kong University Press.

Peel, E. \& Riggs, D. W. (2016). Lesbian, gay, bisexual, transgender psychologies. In The Wiley Blackwell encyclopedia of gender and sexuality studies. (pp. 1-6) London: John Wiley. DOI: 10.1002/9781118663219.wbegss137 